\title{
The Correlation Between Lipid Profile and Xanthelasma
}

\author{
Puridelko Kampar, Qaira Anum, Sri Lestari \\ Departement of Dermatology and Venereology, Faculty of Medicine, Universitas Andalas/Dr. M. \\ Djamil Central Public Hospital Padang, Indonesia
}

\begin{abstract}
Background: Xanthelasma is an abnormal lipid deposition on palpebrae, which is observable as yellowish plaque or nodules. Its incidence is $0.56-1.5 \%$ with onset of 15-73 years old and mostly occurs in the fourth and fifth decade. Few reports of xanthelasma did not cover the correlation between lipid profile and xanthelasma in Indonesia. Purpose: To find a correlation between lipid profile with xanthelasma in Dr. M. Djamil Hospital, Padang. Methods: This was an analytic cross-sectional study with consecutive sampling. There were 36 participants (18 xanthelasma and 18 control). Result: The highest age group was $>36-\leq 45$ years old $(38.89 \%)$. More cases were observed in female $(66.67 \%)$. Body mass index examination of xanthelasma revealed that most were overweight $(55.56 \%)$. Grade I xanthelasma was the most common $(72.22 \%)$. The cholesterol serum level of xanthelasma patients was higher than the subject controls $(224.61 \pm 29.77 \mathrm{mg} / \mathrm{dl}$ versus $169.39 \pm 35.84$ $\mathrm{mg} / \mathrm{dl})(\mathrm{p}<0,05)$. The High Density Lipoprotein (HDL) serum level of xanthelasma patients was lower than controls $(46.44 \pm 14.19 \mathrm{mg} / \mathrm{dl}$ versus $51.78 \pm 15.9 \mathrm{mg} / \mathrm{dl})(\mathrm{p}>0,05)$. The Low Density Lipoprotein (LDL) serum level of xanthelasma patients was higher than control $(139.39 \pm 29.73 \mathrm{mg} / \mathrm{dl}$ versus $106.50 \pm 35.43 \mathrm{mg} / \mathrm{dl})(\mathrm{p}<0,05)$. Triglyceride serum level of xanthelasma patients was higher than the controls $(167.83 \pm 87.26 \mathrm{mg} / \mathrm{dl}$ versus $121.61 \pm 54.52 \mathrm{mg} / \mathrm{dl})(\mathrm{p}>0,05)$. Conclusion: There was a correlation between higher cholesterol and LDL serum level with xanthelasma. No correlation between lower HDL and a higher triglyceride serum level with xanthelasma.
\end{abstract}

Keywords: xanthelasma, lipid profile.

Correspondence: Puridelko Kampar, Departement of Dermatology and Venereology /Faculty of Medicine Universitas Andalas/DR. M. Djamil Central Public Hospital, Padang, Indonesia. Phone: +6751 810125, 081363307465, e-mail: puridelko@yahoo.co.id

\section{BACKGROUND}

Xanthelasma is the most common form of cutaneous xanthoma, an abnormal lipid deposition on the eyelids, and it presents an as yellowish plaque or nodule. ${ }^{1-3}$ Xanthelasma might feel tender, soft, semisolid, or calcareous upon palpation. Xanthelasma is usually symmetrical, might occur on the whole eyelid and might expand permanently. ${ }^{1,2,4,5}$

The incidence of xanthelasma varies around $0.56-1.5 \%$ worldwide, the age of onset is $15-73$ years old, and most cases occur in the fourth and fifth decade of life..$^{2,3,6-8}$ A study by Laftah in London (2018) stated that the prevalence of xanthelasma was $4 \%$, with a $0.3 \%$ incidence in men and $1.1 \%$ in women. ${ }^{9}$ The incidence of xanthelasma in Copenhagen (2011) was $4.4 \%$ and $0.09 \%$ in South Korea in $2017 .{ }^{10,11}$ Xanthelasma is more common in women than men, and its incidence increases with age. 1,6,7,12-14 There were 91 patients with xanthelasma in the outpatient clinic of the Dermatovenereology Department, Faculty of Medicine of Universitas Indonesia/Cipto Mangunkusumo Hospital from 2007 to 2009. ${ }^{2}$ The xanthelasma incidence in the outpatient clinic of Mataram Hospital was $18.2 \% .{ }^{15}$ In the outpatient clinic of Dermatovenereology Department of Dr. M. Djamil
Central Public Hospital Padang, there were 16 new xanthelasma patients between 2013 and 2017. ${ }^{16}$

Patients usually present with complaints of cosmetical disorder, which often makes them less confident; therefore, affecting their quality of life. However, to our knowledge, there has been no xanthelasma study which uses the Dermatology Life Quality Index (DLQI). Those studies usually only mention how xanthelasma alters the patient's quality of life cosmetically to the point that it interferes with their daily activity. Therefore, early detection is needed to prevent cosmetical disorder, lack of confidence, and less quality of life. These studies did not present quantitative data on how much xanthelasma affect cosmetic aspect, sense of confidence, and quality of life. . $^{1,5,17-20}$

Xanthelasma has been considered as a marker for atherosclerosis, which is the main factor of cardiovascular diseases. Recently, the incidence of metabolic diseases tends to increase due to lifestyles, dietary habit, and metabolic disorder, which also increases the incidence of xanthelasma. ${ }^{1,5,17-20}$ Dwivedi et al., conducted a study on xanthelasma as a marker for atherosclerosis in India. The study concluded that there was a tendency of coronary arterial disease and 
asymptomatic atherosclerosis in familial xanthelasma. $^{21}$ Dey reported xanthelasma cases in individuals with other predisposing factors such as smoking, central obesity, hypertension, diabetes mellitus, and dyslipidemia in India. These are the main risk factors for congestive arterial disease. Furthermore, Zac in the Czech Republic (2014) reported that xanthelasma correlates to an increased risk for atherothrombotic disease. ${ }^{3,4,21,22}$ It is presumed that xanthelasma can act as a marker for dyslipidemia and also it might predict the possibility of someone acquiring coronary artery disease due to dyslipidemia. Therefore the occurrence of xanthelasma in an individual should make health workers aware of dyslipidemia and atherosclerosis. ${ }^{4,23}$

The main pathogenesis of xanthelasma is unclear, although several factors might take part, such as dyslipidemia, hormonal factors, local factors, and macrophages, acetylated Low Density Lipoprotein (LDL) and macrophages with scavenger receptor. ${ }^{24}$ In Italy, Caputo $\mathrm{R}$ reported one xanthelasma case in a normolipidemic patient. ${ }^{25}$ There were also reports from Bergman $\mathrm{R}$ in the United States and Sharma SB in India that stated $20-70 \%$ xanthelasma in normolipidemic patients. ${ }^{7,8}$ In contrary to the studies mentioned above, a study by Christoffersen in Copenhagen (2011) reported the ratio of myocardial infarct was 1.48 in xanthelasma patients compared to control group (mean 1.231.79; confidence interval $95 \%), 1.39$ (1.201.60) for ischemic heart disease, 0.94 $(0.731 .21)$ for ischemic stroke, and $0.91(0.721 .15)$ for ischemic cerebrovascular disease, and 1.14 (1.041.26) for the mortality rate. ${ }^{26}$

About $50 \%$ of xanthelasma cases were reported with hyperlipidemia (increased serum cholesterol). Xanthelasma with hyperlipidemia correlates to its underlying primary or secondary disease, while in normolipidemic patients, other contributing factors are hormonal and genetic factors. Xanthelasma in young adults with familial history of hyperlipidemia should be suspected of the presence of lipid metabolism disorder. ${ }^{1,7,17,24}$ The lipid profile is a summary of the blood lipid level. A number of properties checked in lipid profiles are cholesterol, High Density Lipoprotein (HDL), LDL, and triglycerides. The normal level of cholesterol is $<200 \mathrm{mg} / \mathrm{dl}$, HDL $>40 \mathrm{mg} / \mathrm{dl}, \mathrm{LDL}<100$ $\mathrm{mg} / \mathrm{dl}$, and triglycerides $<150 \mathrm{mg} / \mathrm{dl}^{27-29}$

A study by Ozdol in Turkey (2008) compared 100 xanthelasma patients with a control group, and the study concluded that xanthelasma patients also had dyslipidemia. ${ }^{20}$ A study by Noel in Swiss (2007) reported that, out of 17 xanthelasma patients aged 31 73 years old and 21 control patients aged 23-75 years old, there were 7 people with normolipidemic xanthelasma and 8 hyperlipidemic people without xanthelasma. ${ }^{30}$ Furthermore, a study by Dey in India (2013) reported that out of 61 xanthelasma patients, there were 12 dyslipidemic patients, and 49 normolipidemic patients, while out of 130 individuals in the control group, there were 28 dyslipidemic and 102 normolipidemic individuals. ${ }^{4}$ Szalat et al. in Italy (2011) reported that 2 out of 24 patients were hyperlipidemic. ${ }^{31}$ Bergman in Israel in 1994 reported normal cholesterol and triglycerides level in xanthelasma patients. ${ }^{32}$ To the knowledge of the authors, there has been no study evaluating the correlation between lipid profile and xanthelasma in Indonesia. Therefore, we were motivated to investigate the topic.

\section{METHODS}

This was a cross-sectional, observational analytic study. The study aimed to evaluate the correlation between lipid profile and xanthelasma. The inclusion criterion was xanthelasma patients (new and old cases) aged $>18$ years old who are willing to participate in the study by signing informed consent. The exclusion criterion was patients whose under lipid treatment within the last one month. We used a consecutive sampling method, choosing the subjects based on attendance at the Dermatovenereology outpatient clinic of Dr. M. Djamil Hospital, Padang. This study has approved an ethical clearance from Dr. M. Djamil Hospital, Padang.

\section{RESULT}

The group with the highest prevalence of xanthelasma was the $>41-\leq 50$ years old $(38.89 \%)$. There were more women with xanthelasma than men $(66.67 \%)$. The mean age of the xanthelasma group was $48.61 \pm 12.36$ years old, and the mean onset was on $48.11 \pm 12.27$ years old. The body mass index on the xanthelasma group was $25.33 \pm 1.13$. Grade I of xanthelasma was the most commonly found, which was $72.22 \%$. More than two-thirds of the study sample had the age onset of $>40$ years old $(61.11 \%)$ (Table 1$)$.

The xanthelasma group had a higher total cholesterol level, which was $224.61 \pm 29.77 \mathrm{mg} / \mathrm{dl}$, than the control group, which was $169.39 \pm 35.84 \mathrm{mg} / \mathrm{dl}$ $(p<0,05)$. This group had a lower HDL level, which was $46.44 \pm 14.19 \mathrm{mg} / \mathrm{dl}$, than the control group, which was $51.78 \pm 15.94 \mathrm{mg} / \mathrm{dl}(\mathrm{p}>0,05)$. The LDL level that was $106.50 \pm 35.43 \mathrm{mg} / \mathrm{dl}$ was higher than that of the control group, which was $106.50 \pm 35.43 \mathrm{mg} / \mathrm{dl}$. The summary of the triglycerides level of the xanthelasma and control group can be seen in Table 2. The triglycerides level in the xanthelasma group, $167.83 \pm 87.26 \mathrm{mg} / \mathrm{dl}$, was higher than that of the 
control group, which was $121.61 \pm 54.52 \mathrm{mg} / \mathrm{dl}$ $(\mathrm{p}>0,05)$.

There was a tendency of a positive correlation of the cholesterol levels on xanthelasma patients compared to the control group. The correlation test result showed that the cholesterol and LDL level between xanthelasma and controls was statistically significant if $p<0.05$. The cholesterol and HDL level between xanthelasma and controls were statistically not significant if $\mathrm{p}>0.05$.

Table 1. The distribution of xanthelasma patients and control subjects in Dr. M. Djamil Hospital Padang, January - December 2018

\begin{tabular}{|c|c|c|c|c|c|}
\hline Characteristics & $\begin{array}{c}\text { Xanthelasma } \\
\mathrm{f}(\mathrm{n}=18)\end{array}$ & $(\%)$ & $\begin{array}{c}\text { Control } \\
\mathrm{f}(\mathrm{n}=18)\end{array}$ & $(\%)$ & $\mathrm{p}$ \\
\hline \multicolumn{6}{|l|}{ Age } \\
\hline$>18-\leq 30$ years & - & - & - & - & \\
\hline$>31-\leq 40$ years & 6 & 33.33 & 6 & 33.33 & \\
\hline$>41-\leq 50$ years & 7 & 38.89 & 7 & 38.89 & \\
\hline$>51-\leq 60$ years & 2 & 11.11 & 1 & 5.56 & \\
\hline$>61$ years & 3 & 16.67 & 4 & 22.22 & \\
\hline Mean \pm standard deviation & $48.611 \pm 12.358$ & & $48.111 \pm 12.266$ & & 0.8 \\
\hline \multicolumn{6}{|l|}{ Sex } \\
\hline Male & 6 & 33.33 & 6 & 33.33 & - \\
\hline Female & 12 & 66.67 & 12 & 66.67 & \\
\hline Body Mass Index (BMI) & & & & & 0.7 \\
\hline Underweight $(<18,4)$ & - & - & - & - & \\
\hline Normal weight $(18,5-24,9)$ & 6 & 33.33 & 16 & 88.89 & \\
\hline Overweight $(25-29,9)$ & 10 & 55.56 & 2 & 11.11 & \\
\hline Obese $(30-39,9)$ & 2 & 11.11 & - & - & \\
\hline \multicolumn{6}{|l|}{ Xanthelasma classification } \\
\hline Grade I & 13 & 72.22 & - & - & \\
\hline Grade II & 3 & 16.67 & - & - & \\
\hline Grade III & 1 & 5.56 & - & - & \\
\hline Grade IV & 1 & 5.56 & - & - & \\
\hline \multicolumn{6}{|l|}{ Age of onset for xanthelasma } \\
\hline$\leq 40$ years & 7 & 38.89 & - & - & \\
\hline$>40$ years & 11 & 61.11 & - & - & \\
\hline Mean \pm standard deviation age of onset & $43.389 \pm 10.122$ & & & & \\
\hline
\end{tabular}

Note : frequency $=36 \quad \mathrm{P}=\mathrm{p}$ value $(\mathrm{CI}=95 \%)$

Table 2. Serum lipid profile

\begin{tabular}{|c|c|c|c|}
\hline Lipid profile & Xanthelasma & Control & $\mathrm{p}$ \\
\hline $\begin{array}{l}\text { Total cholesterol } \\
\qquad(\mathrm{mg} / \mathrm{dl})\end{array}$ & $224.61 \pm 29.77$ & $169.39 \pm 35.84$ & $0.000 *$ \\
\hline $\begin{array}{l}\text { HDL } \\
(\mathrm{mg} / \mathrm{dl})\end{array}$ & $46.44 \pm 14.19$ & $51.78 \pm 15.94$ & 0.297 \\
\hline $\begin{array}{c}\mathrm{LDL} \\
(\mathrm{mg} / \mathrm{dl})\end{array}$ & $139.40 \pm 29.73$ & $106.50 \pm 35.43$ & $0.005^{*}$ \\
\hline Triglycerides & $167.83 \pm 87.26$ & $121.61 \pm 54.52$ & 0.065 \\
\hline
\end{tabular}

Note : $\mathrm{SD}= \pm 2 ; \mathrm{P}=0,001$ Cholesterol = 29.77; High Density Lipoprotein $=14.19$; Low Density Lipoprotein $=$ 29.73; Triglyceride $=87.26$ 


\section{DISCUSSION}

The results showed that most patients with xanthelasma were in the $>41-\leq 50$ years age group. This is in line with a study by Dey in India (2013) and Reddy et al., in England (2013) which showed that the highest incidence of xanthelasma cases was in the 3140 and 40-50 years age group. Gangopadadhya et al., (2007) also acquired the highest incidence of xanthelasma cases (30\%) in the 31-40 years age group. A similar result was obtained by Jain in India (2007), in which the majority of xanthelasma patients were 3150 years old (37.9\%). ${ }^{24}$ Chhetri in India in 2008 found that the highest incidence of xanthelasma was from the $40-50$ years age group and $40 \%$ of the cases were from the $30-40$ years age group..$^{17,24}$

Dey in India (2013) found that of 34 males and 27 females xanthelasma patients, 6 patients were $\leq 40$ years old, 45 patients were 40 - 60 years old (73.77\%), and 10 patients were $\geq 60$ years old. The author classified the site of the lesion(s) into unilateral (15 patients), bilateral (30 patients), affecting 3 eyelids (6 patients), and 4 eyelids (10 patients). ${ }^{4,18,32}$

The correlation test of this study was $\mathrm{p}=0.8$ $(\mathrm{p}>0.05)$. Thus, it was inferred that there was no significant difference between the patients' age and the control subjects. Therefore, the age characteristic bias can be minimalized.

The epidemiology data from a number of studies show that xanthelasma is more commonly found in females. ${ }^{2}$ In this study, there were 12 females (66.67\%) and 6 males (33.33\%), with a ratio of 2:1. A study by Anggarwal in India (2016) reported that $80.95 \%$ of xanthelasma cases were females. Similar results were reported by Jain in India (2007) and Gangopadya, Epstein, and Pedace in Brazil in 2016. ${ }^{17,24}$ Kavoussi in Iran (2015) acquired similar result; xanthelasma is more common in females $(85.7 \%)$ than males $(14.3 \%)$; however, this contradicts to a study by Dey in India (2013) who reported that there were more cases in males $(55.7 \%)$ than females $(44.3 \%) .{ }^{4}$ Theoretically, the predominance of xanthelasma in females is due to hormonal factor (estrogen) in the etiopathogenesis of xanthelasma and the deeper concern to cosmetics in females. ${ }^{18}$

A study by Jain in 2007 stated that the age of onset of xanthelasma is highest in the fourth and fifth decade of life. In this study, $61.11 \%$ of patients had the onset age of $>40$ years and $38.89 \%$ of $\leq 40$ years old. A similar result was reported in a study by Kavoussi in 2015 , where $45.23 \%$ were $>40$ years old and $19 \%>$ 50 years old when they first contracted xanthelasma. ${ }^{18}$

The body mass index (BMI) examination revealed that 10 patients $(55.56 \%)$ were overweight, 6 patients (33.33\%) were normoweight, and 2 patients
(11.11\%) were obese. BMI might affect the lipid profile. A study by Akyuz AR in Turkey (2016) found that there was a positive correlation between xanthelasma and the BMI, in which the BMI of xanthelasma patients was $31.2 \pm 5.6$ (overweight). ${ }^{19,33}$

The clinical classification showed that the majority of patients, $72.22 \%$, suffered from grade I xanthelasma. This is following a report by Kavousi in 2015 , in which $57.14 \%$ of research subjects suffered mild grades. ${ }^{18}$ Jain classified xanthelasma based on palpebral involvement instead of grading. The study reported that the majority of patients, which was $91.0 \%$ suffered from multiple lesion. In $87.9 \%$ of the cases, xanthelasma affected two or more eyelids. A study by Chetri and Ribera also reported that xanthelasma affected two or more eyelids in most of the patients. ${ }^{24}$

Kavousi in 2015 reported a mean cholesterol level of $221.51 \pm 60.4 \mathrm{mg} / \mathrm{dl}$ in xanthelasma patients. ${ }^{18}$ In this study, the total cholesterol level was $224.61 \pm 29.77 \mathrm{mg} / \mathrm{dl}$ in affected patients, which was higher than that in control subjects, $169.39 \pm 35.83$ $\mathrm{mg} / \mathrm{dl}$. Corresponding to a study by Pandhi in India, there was a similar result. The study reported an increased cholesterol level in xanthelasma patients compared to the control group. ${ }^{19}$

Pandhi reported that $67.5 \%$ of xanthelasma patients had normal cholesterol levels. ${ }^{19}$ In this study, there were two patients (22.22\%) with normal cholesterol levels $(<200 \mathrm{mg} / \mathrm{dl})$. Cases of xanthelasma with normal lipid levels (normolipid) were reported by Noel in Swiss in 2007. The same study also reported the risk of premature carotid atherosclerosis in xanthelasma patients, both normolipidemic and hyperlipidemic. It is then inferred that there is an increased risk of cardiovascular disease in xanthelasma patients. ${ }^{30}$ The lipid profile can be affected by one's age and sex. In this study, the age and sex between xanthelasma patients and control subjects were equalized to minimize bias. In addition, the test result was $p>0.05$; therefore, the age and sex differences in this study were not statistically significant.

A study by Kavousi in Iran in 2015 reported an HDL level of $36.2 \pm 31.41 \mathrm{mg} / \mathrm{dl}$ and $50.5 \pm 44.5 \mathrm{mg} / \mathrm{dl}$ in control subjects. ${ }^{18}$ This study HDL level of $46.44 \pm 14.19 \mathrm{mg} / \mathrm{dl}$ in patients and $51.78 \pm 15.94 \mathrm{mg} / \mathrm{dl}$ in the control group, which is less than the normal level, $<40 \mathrm{mg} / \mathrm{dl}$. Our study obtained similar results to that of Kavousi's, in which the HDL level of xanthelasma patients was lower compared to the control group. This is in accordance with a study by Pandhi, where the HDL level of xanthelasma patients was lower. ${ }^{19}$

High-density lipoprotein is a non-atherogenic lipid component. At its low level, the atheroprotective 
component in the body that protects from atherosclerosis is also decreased. In contrary, if the HDL level is high, the risk for atherosclerosis decreases; therefore, reducing the risk of coronary heart disease and stroke. ${ }^{34}$

Kavousi's study reported the mean LDL level of $120.3 \pm 43.6 \mathrm{mg} / \mathrm{dl}$ in affected individuals and $110.6 \pm 26.7 \mathrm{mg} / \mathrm{dl}$ in the control group. ${ }^{18}$ This study found that the mean of LDL level of xanthelasma patients was $139.40 \pm 29.73 \mathrm{mg} / \mathrm{dl}$, which was higher than the control group, $106.50 \pm 35.43 \mathrm{mg} / \mathrm{dl}$. Pandhi also obtained similar results, an higher LDL level in xanthelasma patients compared to the control group. ${ }^{19}$ A study by Akyus in 2016 acquired identical result; the LDL level ( $142 \pm 45$ versus $115 \pm 36 \mathrm{mg} / \mathrm{dl}, \mathrm{p}=0.003$ ) in xanthelasma compared to the controls. ${ }^{33}$

Low Density Lipoproteins serve as a carrier for cholesterol, triglycerides, and other blood fat to various parts of the body. Specifically, the main function of LDL is to transport cholesterol from the liver to tissues by mounting it to the cell membrane. ${ }^{35}$ A lower LDL level is low will result in cholesterol buildup in the blood. This will facilitate acetylation and cholesterol leakage from the blood vessel, causing xanthelasma. $^{2,6}$

Kavousi in 2015 reported triglyceride level of $185.98 \pm 71.7 \mathrm{mg} / \mathrm{dl}$ in xanthelasma patients and $149.39 \pm 94.2 \mathrm{mg} / \mathrm{dl}$ in the control group. ${ }^{18}$ In this study, the triglyceride level of the patients' group was $167.83 \pm 87.2611 \mathrm{mg} / \mathrm{dl}$, which was higher than the control group, $121.61 \pm 54.52 \mathrm{mg} / \mathrm{dl}$. This is in accordance with a study by Pandhi which reported a higher triglyceride level in xanthelasma patients compared to the control group. ${ }^{19}$ A study by Akyus in 2016 obtained an identical result, reporting a higher lipid profile level in xanthelasma than the control group. ${ }^{56}$ Age and sex may affect the lipid profile level; however, in this study, age and sex were homogenized.

There has been a tendency to a positive correlation, a higher cholesterol level in xanthelasma patients than the control group. The test showed a statistically significant result between the cholesterol and LDL levels in which $\mathrm{p}<0.05$.

Abnormal lipid metabolism is an important factor in the pathogenesis of xanthelasma. It has been studied that LDL was found along the capillary wall of xanthelasma patients, meaning that the accumulation of cholesterol originates in the blood. Therefore, studies on the relationship between xanthelasma and hyperlipidemia have been largely done to prove whether cholesterol level and LDL were significantly higher in xanthelasma patients compared to control subjects. ${ }^{20}$ A study by Jain involving 66 xanthelasma patients and 50 control subjects, there was a statistically significant rise in cholesterol level (216.8 $\mathrm{mg} / \mathrm{dl}$ in xanthelasma patients and $173.6 \mathrm{mg} / \mathrm{dl}$ in control subjects) with $\mathrm{p}=0.001 \quad(\mathrm{p}<0.05)$ and $\mathrm{CI}=$ $95 \% .^{24}$

Pandhi in India and Kavoussi in Iran reported a statistically significant correlation between cholesterol and xanthelasma. ${ }^{18,19}$ However, Bergman (1994) in United Stated reported the opposite that there were normolipidemic xanthelasma patients. ${ }^{32}$

A higher serum cholesterol level is one of the many major risk factors for coronary heart disease. ${ }^{24}$ Xanthelasma is widely associated with the rise in blood lipid levels, one of which is cholesterol. Therefore, xanthelasma can also serve as a marker to determine the risk factor for coronary heart disease. A focus of therapy is to reduce risk factors by decreasing the cholesterol level. ${ }^{24,35,36}$

A study by Esmat in Egypt (2015) also obtained a similar result, in which the HDL level was not statistically significant between xanthelasma patients and the control group. A study of Esmat compared normolipidemic with hyperlipidemic xanthelasma patients. The study reported that the HDL level of 20 normolipidemic xanthelasma patients was $45.72 \pm 8.00$ $\mathrm{mg} / \mathrm{dl}$ and $45.39 \pm 7.15 \mathrm{mg} / \mathrm{dl}$ in the control group. Additionally, the LDL level of 20 hyperlipidemic xanthelasma patients was $29.14 \pm 3.46 \mathrm{mg} / \mathrm{dl}$, and the control group was $45.39 \pm 7.15 \mathrm{mg} / \mathrm{dl}^{37}$

In Said's study, the risk factors for atherosclerosis were studied and concluded that normolipidemic xanthelasma patients have a higher risk of atherosclerosis than hyperlipidemic xanthelasma patients; therefore, monitoring and early treatment are needed. ${ }^{37}$ In this study, there were 8 patients (44.44\%) with an HDL level of $<40 \mathrm{mg} / \mathrm{dl}$, in which HDL is an atheroprotective lipid against blood vessel atherosclerosis risk factors. It is then suggested that patients should have early monitoring of their atherosclerosis risk factors.

Higher LDL level in xanthelasma groups compare to controls also reported by Akyus from Turkey in 2016, Kavousi from Iran in 2015, and Pandhi from India in 2012. ${ }^{18,19,33}$ It is contrary to the results from Esmat's study (2015), where the LDL levels were not statistically significant in the xanthelasma and control group. The study recorded that LDL level in normolipidemic xanthelasma patients was $106,25 \pm 18,69 \mathrm{mg} / \mathrm{dl}$ and controls was $99,79 \pm 26,24 \mathrm{mg} / \mathrm{dl}$; in hyperlipidemic xanthelasma patients $134 \pm 26,51 \mathrm{mg} / \mathrm{dl}$ and controls was $106,25 \pm 18,69 \mathrm{mg} / \mathrm{dl}^{37}$

Low Density Lipoproteins serve as a carrier for cholesterol, triglycerides, and other blood fat to various parts of the body. Specifically, the main 
function of LDL is to transport cholesterol from the liver to tissues by mounting it to the cell membrane. ${ }^{35}$ A lower LDL level is low will result in buildup in the blood. This will facilitate acetylation and cholesterol leakage from the blood vessel, causing xanthelasma. ${ }^{2,6}$

Akyus in 2016 reported a higher triglyceride level in xanthelasma than in the control group. ${ }^{33}$ The study also reported significantly higher triglyceride levels in xanthelasma patients compared to the control group (154 versus $101 \mathrm{mg} / \mathrm{dl}, \mathrm{p}=0.01$ ). In this study, there was a not significant rise in the triglyceride level between the xanthelasma patients and the controls subjects. Increased serum cholesterol and LDL level correlated to xanthelasma $(p<0.05)$. However, a decreased serum HDL and increased serum triglycerides level were not proven to be associated with xanthelasma.

\section{REFERENCES}

1. Schaefer EJ, Santos RD. Xanthomatoses and lipoprotein disorders. In: Goldsmith LA, Katz SI, Gilchrest BA, Paller AS, Leffell DJ, Wolff K, editors. Fitzpatrick's dermatology in general medicine. $8^{\text {th }}$ ed. New York: McGraw-Hill; 2012. p. 1600-12.

2. Wulandari N, Nilasari H, Cipto H. Xantelasma, gambaran klinis dan penatalaksanaan. MDVI 2013; 40(1): 46-55.

3. Sharma P, Patgiri D, Sharma G, Pathak MS. Serum lipid profile in xanthelasma palpebrum. Indian Journal of Basic and Applied Medical Research 2013;7(2): 732-7.

4. Dey A, Aggarwal R, Dwivedi S. Cardiovascular profile of xanthelasma palpebrarum. BioMed Research International 2013: p. 1-3.

5. Greijmans E, Welkenhuyzen HL, Luijks $H$, Bovenschen HJ. Continuous wave potassium titanyl phosphate laser treatment is safe and effective for xanthelasma palpebrarum. American Society for Dermatologic Surgery 2016; 42: 8606.

6. Nair PA, Singhai R. Xanthelasma palpebrarum-A brief review. Clinical, Cosmetic and Investigational Dermatology 2018; 11: 1-5.

7. Bergman R, Friedman-Birnbaum R, Aviram M, Katz I, Kerner H, Brook J. Adult xanthogranulomatosis associated with abnormal apolipoprotein levels. Clinical Experimental Dermatology 1990;15: 372-5.

8. Sharma SB, Dwivedi S, Prabhu KM, Kumar N, Baruah MC. Preliminary studies on serum lipids, apolipoprotein-B and oxidative stress in xanthelasma. Indian Journal of Clinical Biochemistry 1999; 14(2): 245-8.
9. Laftah Z, Al-Niaimi F. Xanthelasma: An update on treatment modalities. Journal of Cutaneous and Aesthetic Surgery 2018; 11(1): 1-6.

10. Zak A, Zeman M, Slaby A, Vecka M. Xanthomas: Clinical and pathophysiological relations. Biomed Pap Med Fac Univ Palacky Olomouc Czech Repub 2014; 158(2): 181-8.

11. Jung SY, Hwang NH, Yoon ES, Park SH. Erbium: Yttrium aluminum garnet laser treatment for xanthelasma palpebrarum. Medical Lasers; Engineering, Basic Research, and Clinical Application 2017; 6(1): 24-8.

12. Jonsson A, Sigfusson N. Significance of xanthelasma palpebrarum in the normal population. Lancet 1976; 372-4.

13. Segal P, Insull W J, Chambless LE. The association of dyslipoproteinemia with corneal arcus and xanthelasma. Circulation 1986; 1108-18.

14. Roederer GO, Bouthillier 0, Davignon J. Xanthelasma palpebrarum and corneal arcus in octogenarians. N Engl J Med 1987; 1740.

15. Hidajat D, Hapsari Y, Hendrawan IW. Karakteristik penyakit kulit pada geriatri di Poliklinik kulit dan kelamin RSUD Provinsi Nusa Tenggara Barat periode 2012-2014. Jurnal Kedokteran Universitas Mataram 2017; 6(4): 7-13.

16. Zagoto YES, Lestari S, Asri E. Profile of xanthelasma during Januari 2014-December 2017 in Dermato-Venereology outpatient clinic of Dr. M. Djamil hospital Padang. Regional Confrence of Dermatology 2018. Surabaya, Indonesia.

17. Aggarwal R, Rathore PK. A study evaluating xanthelasma palpebrarum clinically and biochemically. International Journal of Contemporary Medical Research 2016; 3(9): 25657.

18. Kavoussi. Serum lipid profile and clinical characteristics of patients with xanthelasma palpebrarum. An Bras Dermatol 2016; 468-71.

19. Pandhi D, Gupta P, Singal A, Tondon A, Sharma SB, Madhu SV. Xanthelasma palpebrarum: A marker of premature atherosclerosis (risk of atherosclerosis in xanthelasma). Postgrad Med J 2012; 88: 198-204.

20. Özdöl S, Sahin S, Tokgözoglu L. Xanthelasma palpebrarum and its relation to atherosclerotic risk factors and lipoprotein (a). The International Society of Dermatology International Journal of Dermatology 2008; 47: 785-9.

21. Dwivedi S, Aggarwal A, Singh S, Sharma V. Familial xanthelasma with Dyslipidemia: Just Another Family Trait?. North American Journal of Medical Sciences 2012; 4: 238-40. 
22. Sarkany RPE, Breathnach SM, Seymour CA, Weismann K, Burns DA. Metabolic and nutritional disorders. In: Burns $\mathrm{T}$, Breathnach S, Cox N, Griffiths C, editors. Rook's textbook of dermatology. $7^{\text {th }}$ ed. Massachusetts: Blackwell Science; 2004. p. 57.66.

23. James WD, Berger TG, Elston DM. Andrews's diseases of the skin clinical dermatology. $9^{\text {th }}$ ed. Canada : Elsevier Incorporation; 2009. p.528-32.

24. Jain A, Goyal P, Nigam PK, Gurbaksh H, Sharma RC. Xanthelasma palpebrarum: Clinical and biochemical profile in a tertiary care hospital of Delhi. Indian Journal of Clinical Biochemistry 2007; 22(2): 151-3.

25. Caputo R, Monti M, Berti E. Normolipemic eruptive cutaneous xanthomatosis. Arch Dermatol 1986; 122: 1294-7.

26. Christoffersen M, Schmidt RF, Schnohr P, Jensen GB, Nordestgaard BG, Hansen AT. Xanthelasmata, arcus corneae, and ischaemic vascular disease and death in general population: prospective cohort study. British Medical Journal 2011(343): 731-5.

27. Arifah. Peran lipoprotein dalam pengangkutan lemak tubuh. Ed Arifah. Dalam Kaunia Jakarta: EGC; 2006. p. 121-34.

28. Santoso A. PERKI. Pedoman tatalaksana dislipidemia. Jakarta: Centra Communications; 2013. p. 5-27.
29. Turgeon RD, Anderson TJ, Gregoire J, Pearson GJ. 2016 Guidelines for the management of dyslipidemia and the prevention of cardiovascular disease in adults by pharmacist. Canadian Journal Cardiology 2016; 32: 1263-82.

30. Noël B. Premature atherosclerosis in patients with xanthelasma. Journal of European Academy of Dermatology and Venereology 2007; (21): 12448 .

31. Szalat R. Pathogenesis and treatment of xanthomatosis associated with monoclonal gammopathy. The Am Soc of Hem 2011; 3777-83.

32. Bergman R. The pathogenesis and clinical significance of xanthelasma palpebrarum. J Am Acad Dermatol 1994; 30: 236-42.

33. Akyuz AR. Xanthelasma is associated with an increase amounth of epicardial adipose tissue. Med Princ Pract 2016; 25(2): 187-90.

34. Ana, Jonas. Lipoprotein structure. USA: Elsevier science; 2002. p. 32-9.

35. Erwinanto. PERKI. Pedoman tatalaksana dyslipidemia. 2013. p. 37-51.

36. Sniderman A, Couture P, Graaf Jd. Nature Review. Endocrinololy 2010; 6: 335-46.

37. Esmat. Risk of atherosclerosis in normolipidaemic patients with xanthelasma. Clinical and Experimental Dermatology 2015; 40: 373-8. 